\title{
Search for Potential Sources of Resistance among Interspecific Derivatives of Peanut against Peanut Bud Necrosis Disease
}

\author{
Muttanna Revadi $^{1 *}$, Gururaj Sunkad ${ }^{1}$, A. Srinivasaraghavan ${ }^{1}$ and S.K. Bera ${ }^{2}$ \\ ${ }^{1}$ Department of Plant Pathology, University of Agricultural Sciences, Raichur-584102, \\ Karnataka, India \\ ${ }^{2}$ Directorate of Groundnut Research, Junagadh-362001, Gujarat, India \\ *Corresponding author
}

A B S T R A C T

K e y w o r d s
$\begin{aligned} & \text { Peanut, Peanut bud } \\ & \text { necrosis virus, } \\ & \text { Interspecific } \\ & \text { derivatives, } \\ & \text { Screening, Hot spot } \\ & \text { and mechanical } \\ & \text { inoculation }\end{aligned}$
Article Info
$\begin{aligned} & \text { Accepted: } \\ & \text { 20 December } 2017 \\ & \text { Available Online: } \\ & \text { 10 January } 2018\end{aligned}$

\section{Keywords}

Peanut, Peanut bud necrosis virus, (nterspecific

Screening, Hot spot and mechanical inoculation
Out of 419 peanut interspecific derivatives, screened over four seasons in epiphytotic field (Hot spot location) and glasshouse conditions, seven genotypes viz., CS-43, CS-54, CS-55, CS-73, CS-77, CS-82 and CS-104 were confirmed as potential resistant with least disease incidence, high dry pod yield, desirable yield and pod features besides longer DFSA, DLSA and $t_{50}$. Further significant positive correlation was found between $t_{50}$ and DFSA, PBND (\%) and DLSA. However, negative correlation was recorded between PBND (\%) and $\mathrm{t}_{50}$, PBND (\%) and DFSA. In glasshouse test, all cross inoculated with PBNV and subsequently produced leaves of resistant genotypes showed presence of virus revealed the block in the systemic virus movement. Perhaps this is first attempt in searching for PBND resistance in interspecific derivatives of peanut and these genotypes can be better utilized in resistant breeding programme for PBND resistant agronomically high yielding varieties.

\section{Introduction}

Peanut (Arachis hypogaea L.) also known as groundnut, is considered as poor man's badam due to its dual qualities viz., high oil (44-56\%) and protein $(22-30 \%)$ content and is grown under varied crop production systems. Due to several biological and environmental constraints the average productivity is often below one tonne per hectare (Mace et al., 2006). Presently growing most of the cultivars have been released on the basis of its superior yield and acceptable seed quality performance. If there is a restriction in use of pesticides, farmers has to agree with lower yields or use resistant varieties (Gopal et al., 2010). In recent years, peanut bud necrosis disease (PBND) is considered as important disease of peanut in south and south-east Asia (Lava kumar et al., 2007a; Reddy et al., 1992). PBND is caused by Peanut bud necrosis virus (PBNV) and vectored by Thrips palmi Karny in a propagative manner (Vijayalakshmi et al., 1995). The PBND incidence ranged from 5-80 
$\%$ and reported to cause yield loss up to $50 \%$ with worth of more than $\$ 89$ million in India alone (Ghanekhar et al., 1979; Reddy et al., 1991; Patil 1993; Reddy et al., 2000). In India, on the basis of PBND severity, Raichur (Karnataka, India) has been identified as one among the seven "hot-spots" for PBND (Basu 1995). In field condition, genotypes can reacts differentially to PBND incidence due to cumulative effects of resistance to virus and resistance to vector (Gopal et al., 2010). The decrease in the yield loss with delayed infection may be attributed to adult plant resistance (Nagarajan and Muralidharan 1995).

Several studies have identified number genotypes as a resistant or moderately resistant in field test but meager attempts were made on categorisation of genotypes on the basis glasshouse tests, yield and pod features. In contrast, several wild Arachis species have been identified as resistant to PBND, due to interspecific compatibility there has been limited success in transferring resistance in to cultivated peanut (Murthy and Jhanvi, 1983). Hence, identification of genotypes with low disease incidence both in hot spot locations and glasshouse condition along with desirable pod features of farmers is need of the hour. Keeping this in view, 419 interspecific derivatives of peanut were screened rigorously under epiphytotic field condition for four cropping seasons and once in glasshouse condition by infective sap inoculation.

\section{Materials and Methods}

\section{Field conditions}

About 419 interspecific derivatives of peanut were collected from Directorate of Groundnut Research (DGR, Junagadh, Gujarat, India) and were evaluated for PBND resistance by employing infector row technique under epiphytotic condition during kharif- 2010 and rabi/summer-2010-11 seasons. A susceptible check (cv. KRG-1) was planted with spacing of 45 and $15 \mathrm{~cm}$ between rows and plants respectively and initial plant count was recorded in all genotypes at 15 DAS and infected plants were marked with bamboo sticks $(0.5 \mathrm{~m})$ to avoid missing of early infected plants as they usually die (Gopal et al., 2010). The PBND reaction in each genotypes was recorded a week before harvest of the crop. Finally, PBND incidence (\%) was calculated as follows and genotypes were designated into different categories following 0-5 scale (Gururaj Sunkad et al., 2001).

Number of PBND plants PBND incidence $(\%)=--------------X 100$

Total number of plants observed

\begin{tabular}{|c|c|l|}
\hline Scale & $\begin{array}{c}\text { Per cent } \\
\text { incidence }\end{array}$ & Disease reaction \\
\hline 0 & 0 to $1 \%$ & Highly resistant \\
\hline 1 & 1.1 to $5 \%$ & Resistant \\
\hline 2 & 5.1 to $10 \%$ & $\begin{array}{l}\text { Moderately } \\
\text { resistant }\end{array}$ \\
\hline 3 & 10.1 to $25 \%$ & $\begin{array}{l}\text { Moderately } \\
\text { susceptible }\end{array}$ \\
\hline 4 & 25.1 to $50 \%$ & Susceptible \\
\hline 5 & $\begin{array}{c}50.1 \% \text { and } \\
\text { above }\end{array}$ & $\begin{array}{l}\text { Highly } \\
\text { susceptible }\end{array}$ \\
\hline
\end{tabular}

The twenty genotypes which behaved as resistant to PBND with desirable yield and pod features during 2010-11 were selected and screened further under epiphytotic field condition during kharif- 2011 and rabi/summer- 2011-12 seasons.

\section{Yield parameters and pod features}

Genotypes which showed field resistance to PBND in four cropping seasons (kharif- 2010, 2011 and rabi/summer- 2010-11, 2011-12) were examined for their yield and its 
parameters viz., dry pod yield, shelling per cent, 100 seed weight, sound matured kernels, oil content and pod parameters.

a) Dry pod yield: Dry pods collected from five randomly selected plants in each genotypes are weighed and average weight was calculated.

b) Shelling per cent: $100 \mathrm{~g}$ of dry pods were taken randomly from each genotype and the kernels obtained after shelling of these pods were weighed and shelling per cent was calculated as follows.

Shelling $(\%)=\frac{\text { Kernel weight }}{\text { Pod weight }}$

c) 100 seed weight: 100 kernels from each genotype were selected randomly and their weight was recorded in grams.

d) Sound matured kernels (SMK): 100 kernels were taken randomly and number of sound matured kernels was counted among them to record per cent SMK

e) Oil content: $30 \mathrm{~g}$ kernels of each genotype was taken randomly and subjected for analysis of oil content through Nuclear Magnetic Resonance method (Ramamurthi et al., 1985) at MARS, Raichur, Karnataka, India.

f) Pod features: The pod features of each genotype was studied based on the observation of pod like beak, constriction and reticulation etc.

\section{Glasshouse conditions}

Genotypes which documented as PBND resistant along with good yield and pod features during kharif- 2010 and rabi/summer2010-11 seasons were selected for screening in glasshouse study.
There are two experiments were conducted to know the resistance of the genotypes to PBND. A PBNV isolate which was maintained on diagnostic host plant (Cowpea cv.C-152) was used as a source inoculum at a dilution of $1 / 100$.

In both experiments ten day old seedlings were mechanically inoculated by using PBNV infective plant sap $(1: 10 \mathrm{w} / \mathrm{v})$ with inoculation buffer (potassium phosphate-0.05 M) at $\mathrm{pH}$ 7.2 (Lava kumar et al., 2007b).

\section{Experiment no.1}

In first experiment the relation between $t_{50}$ (Days taken by plants to reach $50 \%$ of their final incidence), DFSA (Days taken for first symptom appearance), DLSA (Days taken for last symptom appearance) and PBND (\%) incidence in peanut genotypes were studied. Each genotype was sown in 20 pots consisting 3seedlings/pot along with KRG-1 and inoculated mechanically with PBNV infective sap. The number of infected plants in each genotype was recorded on alternate days from $5^{\text {th }}$ day of inoculation until 25 days after inoculation. The $t_{50}$ was determined by calculating the days taken by plants to reach $50 \%$ of their final incidence and DFSA, DLSA and PBND incidence (\%) were calculated. The data collected in glasshouse test were analysed statistically using IBM SPSS statistics software.

\section{Experiment no.2}

The second experiment was conducted to know the resistance mechanism associated with resistant genotypes. Here each genotype was sown in five pots consisting of 3seedlings/pot and a PBNV infective sap was inoculated to all genotypes along with KRG-1. The mean per cent of infection in inoculated and subsequently produced leaves was recorded based on the symptomatic expression 
from all five pots of each genotype. All the inoculated and systemically infected leaves were employed to direct antigen-coating enzyme linked immunosorbent assay (DACELISA) know the presence of PBNV.

\section{Results and Discussion}

\section{Field conditions}

Screening of 419 interspecific derivatives of peanut under epiphytotic field conditions in two rainy and two post-rainy seasons (20102012) revealed occurrence of promising sources of resistance to PBNV. The susceptible check (cv. KRG-1) was recorded PBND incidence of $52 \%$ in rainy and $49.5 \%$ in post-rainy seasons besides $100 \%$ of incidence in glasshouse tests and this amount disease pressure was adequate for screening the genotypes. The several peanut genotypes with field resistance to PBND have been identified (Amin, 1985; Reddy et al., 1991; Dwivedi et al., 1993, 1995; Gururaj Sunkad et al., 2001).

Based on the mean incidence over four seasons, 20 genotypes recorded less than 5\% of incidence and these were chosen for evaluation of resistance to PBNV under glasshouse conditions (Table 1). Among 20 field resistant genotypes, the eleven genotypes viz., CS-83 (11\%), CS-86 (14\%), CS-92 (13\%), CS-94 (16\%), CS-120 (11\%), CS-137 (12\%), CS-156 (14\%), CS-202 (12\%), CS-246 (12\%), CS-262 (13\%) and CS-268 (18\%) exhibited moderately susceptible reaction to PBNV by recording more than $10 \%$ incidence under glasshouse conditions which were recorded less than 5\% incidence in field conditions (Table 1) suggest that the resistance is of quantitative nature and reduced the disease incidence in the crop. There are nine genotypes viz., CS-43, CS-45, CS-51, CS-54, CS-55, CS-73, CS-77, CS-82 and CS-104 which exhibited as resistance reaction in field behaved as moderately resistant in glasshouse tests. The results are in accordance with earlier findings where in genotypes viz., ICGV-0009, ICGV-86699, ICGV-88329, ICGV-91177, ICGV-91234 and ICGV-94252 exhibited partial resistance to PBNV under epiphytotic field and laboratory tests (Gopal et al., 2010). Among nine genotypes, seven genotypes viz., CS-43, CS-54, CS-55, CS-73, CS-77, CS-82 and CS-104 recorded promising yield and yield parameters like pod yield per plant (20.6-25.4g), shelling per cent (71-74\%), 100 seed weight (31-35g), SMK (89-72\%) and oil content (38-40\%) and also desirable pod features of farmers (Table 2).

\section{Glasshouse conditions}

1) Correlation among $t_{50}$, days taken for first symptom appearance (DFSA), last symptom appearance (DLSA) and PBND (\%) incidence indicated significant positive correlation between $t_{50}$ and DFSA (0.812), negative correlation between $\mathrm{t}_{50}$ and PBND (\%) (0.723). Similarly, a positive correlation between PBND (\%) and DLSA (0.604) and negative correlation between PBND (\%) and DFSA (-0.602) also supports the fact that cultivar with high disease pressure will have delayed termination of disease and also early initiation of the disease (Table 3) (Buiel and Parlevliet, 1995).

2) The screening of field resistance genotypes under glasshouse condition revealed the maximum mean per cent of infection of $25 \%$ in inoculated leaves of CS-268 and minimum of $14 \%$ in CS-45 and CS-51. The subsequently produced leaves of CS-43, CS-45 and CS-77 recorded low systemic infection and CS-268 was noticed high infection of $13 \%$ whereas susceptible check (cv. KRG-1) was recorded $100 \%$ of infection (Table 4). 
Table.1 Days to reach 50\% incidence ( $t_{50}$ ), days to first (DFSA) and last (DLSA) appearance of PBND and final PBND incidence in 20 peanut genotypes which showed different levels of

PBND resistance in glasshouse and field test

\begin{tabular}{|c|c|c|c|c|c|c|c|c|}
\hline & & & & & & & $\operatorname{SD}(\%)$ & \\
\hline & & & & & & Field test & & \\
\hline $\begin{array}{l}\text { Sl. } \\
\text { No. }\end{array}$ & Genotypes & $t_{50}$ & DFSA & DLSA & $\begin{array}{l}\text { Rainy } \\
\text { season }^{\text {a }}\end{array}$ & $\begin{array}{c}\text { Post- } \\
\text { rainy } \\
\text { season }\end{array}$ & $\begin{array}{l}\text { Overall } \\
\text { mean }^{c}\end{array}$ & $\begin{array}{c}\text { Glasshouse } \\
\text { test }\end{array}$ \\
\hline 1. & CS-43 & 13 & 10 & 14 & 3.3 & 5.1 & 4.2 & 9 \\
\hline 2. & CS-45 & 14 & 11 & 14 & 3.5 & 4.8 & 4.1 & 8 \\
\hline 3. & CS-51 & 11 & 9 & 12 & 1.7 & 1.6 & 1.6 & 9 \\
\hline 4. & CS-54 & 13 & 10 & 13 & 3.3 & 3.5 & 3.4 & 8 \\
\hline 5. & CS-55 & 12 & 9 & 13 & 1.7 & 1.6 & 1.7 & 9 \\
\hline 6. & CS-73 & 11 & 8 & 12 & 3.4 & 2.0 & 2.7 & 10 \\
\hline 7. & CS-77 & 14 & 9 & 15 & 4.0 & 2.9 & 3.4 & 10 \\
\hline 8. & CS-82 & 11 & 8 & 12 & 2.0 & 2.7 & 2.3 & 10 \\
\hline 9. & CS-83 & 12 & 9 & 14 & 3.8 & 4.3 & 4.1 & 11 \\
\hline 10. & CS-86 & 11 & 8 & 16 & 2.2 & 1.6 & 1.9 & 14 \\
\hline 11. & CS-92 & 10 & 7 & 15 & 3.3 & 3.8 & 3.5 & 13 \\
\hline 12. & CS-94 & 9 & 7 & 15 & 4.6 & 3.7 & 4.1 & 16 \\
\hline 13. & CS-104 & 12 & 8 & 13 & 2.9 & 2.4 & 2.7 & 10 \\
\hline 14. & CS-120 & 13 & 10 & 14 & 3.8 & 4.1 & 3.9 & 11 \\
\hline 15. & CS-137 & 12 & 10 & 14 & 3.0 & 4.2 & 3.6 & 12 \\
\hline 16. & CS-156 & 11 & 9 & 13 & 2.4 & 5.6 & 4.0 & 14 \\
\hline 17. & CS-202 & 12 & 8 & 14 & 3.7 & 2.7 & 3.2 & 12 \\
\hline 18. & CS-246 & 12 & 9 & 14 & 1.1 & 1.2 & 1.2 & 12 \\
\hline 19. & CS-262 & 11 & 8 & 13 & 1.2 & 1.8 & 1.5 & 13 \\
\hline 20. & CS-268 & 10 & 8 & 16 & 3.1 & 3.3 & 3.2 & 18 \\
\hline 21. & KRG- $1^{\mathrm{e}}$ & 8 & 7 & 20 & 52 & 49.5 & 50.8 & 100 \\
\hline
\end{tabular}

a - Mean of two rainy seasons, 2010 and 2011

b - Mean of two post-rainy seasons, 2010-2011 and 2011-2012

c - Mean of 4 (2 rainy and 2 post-rainy) seasons, 2010-2012

$\mathrm{d}$ - Infector row method

e - Susceptible genotype 
Table.2 Incidence of PBND, dry pod yield, yield parameters and pod features of different peanut genotypes

\begin{tabular}{|c|c|c|c|c|c|c|c|c|}
\hline $\begin{array}{l}\text { Sl. } \\
\text { No. }\end{array}$ & Genotypes & $\begin{array}{c}\text { PBND } \\
(\%)\end{array}$ & $\begin{array}{l}\text { Pod } \\
\text { yield per } \\
\text { plant (g) }\end{array}$ & $\begin{array}{c}\text { Shelling } \\
(\%)\end{array}$ & $\begin{array}{c}100 \\
\text { seed } \\
\text { weight }\end{array}$ & $\begin{array}{c}\text { Sound } \\
\text { matured } \\
\text { kernels } \\
(\%)\end{array}$ & $\begin{array}{c}\begin{array}{c}\text { Oil } \\
\text { content } \\
(\%)\end{array} \\
\end{array}$ & $\begin{array}{c}\text { Pod } \\
\text { feature }\end{array}$ \\
\hline 1. & CS-43 & 4.2 & 21.9 & 73 & 33 & 92 & 38 & $\mathrm{D}$ \\
\hline 2. & CS-45 & 4.1 & 20.2 & 67 & 28 & 75 & 32 & ND \\
\hline 3. & CS-51 & 1.6 & 21.5 & 72 & 32 & 88 & 39 & ND \\
\hline 4. & CS-54 & 3.4 & 20.6 & 74 & 33 & 89 & 39 & D \\
\hline 5. & CS-55 & 1.7 & 22.1 & 73 & 32 & 90 & 38 & $\mathrm{D}$ \\
\hline 6. & CS-73 & 2.7 & 21.4 & 72 & 32 & 92 & 41 & $\mathrm{D}$ \\
\hline 7. & CS-77 & 3.4 & 25.4 & 73 & 31 & 91 & 40 & $\mathrm{D}$ \\
\hline 8. & CS-82 & 2.3 & 24.9 & 71 & 32 & 89 & 38 & $\mathrm{D}$ \\
\hline 9. & CS-83 & 4.1 & 22.5 & 74 & 34 & 94 & 39 & $\mathrm{D}$ \\
\hline 10. & CS-86 & 1.9 & 26.7 & 75 & 33 & 88 & 37 & D \\
\hline 11. & CS-92 & 3.5 & 23.9 & 72 & 34 & 91 & 41 & $\mathrm{D}$ \\
\hline 12. & CS-94 & 4.1 & 24.4 & 70 & 29 & 87 & 37 & D \\
\hline 13. & CS-104 & 2.7 & 22.6 & 74 & 35 & 89 & 40 & D \\
\hline 14. & CS-120 & 3.9 & 23.3 & 73 & 33 & 87 & 42 & $\mathrm{D}$ \\
\hline 15. & CS-137 & 3.6 & 26.6 & 73 & 32 & 89 & 37 & $\mathrm{D}$ \\
\hline 16. & CS-156 & 4.0 & 25.6 & 72 & 35 & 91 & 42 & D \\
\hline 17. & CS-202 & 3.2 & 26.3 & 72 & 34 & 88 & 40 & D \\
\hline 18. & CS-246 & 1.2 & 22.1 & 75 & 32 & 91 & 38 & D \\
\hline 19. & CS-262 & 1.5 & 22.4 & 74 & 33 & 87 & 39 & D \\
\hline 20 & CS-268 & 3.2 & 21.2 & 67 & 30 & 87 & 38 & $\mathrm{D}$ \\
\hline 21. & KRG- $1^{c}$ & 50.8 & 17.0 & 65 & 28 & 70 & 35 & ND \\
\hline
\end{tabular}

$\mathrm{D}$ - Desirable

ND - Non desirable

C - Susceptible check 
Table.3 Correlation coefficient of four epidemiological parameters $t_{50}$, PBND $\%$, DLSA and DFSA

\begin{tabular}{|l|c|c|c|c|}
\hline & $\mathbf{t}_{\mathbf{5 0}}$ & PBND \% & DLSA & DFSA \\
\hline $\mathbf{t}_{\mathbf{5 0}}$ & 1 & & & \\
\hline PBND\% & $-0.723^{\mathrm{a}}$ & 1 & & \\
\hline DLSA & -0.108 & $0.604^{\mathrm{a}}$ & 1 & 1 \\
\hline DFSA & $0.812^{\mathrm{a}}$ & $-0.602^{\mathrm{a}}$ & -0.164 & \\
\hline
\end{tabular}

$\mathrm{a}-$ indicates significance at $0.01 \%$ level

Table.4 Screening of peanut genotypes for resistance to PBNV under glasshouse condition

\begin{tabular}{|c|c|c|c|c|c|}
\hline \multirow{2}{*}{ Sl. No. } & \multirow{2}{*}{ Genotypes } & \multicolumn{2}{|c|}{ Inoculated leaves } & \multicolumn{2}{|c|}{$\begin{array}{l}\text { Subsequently produced } \\
\text { leaves }\end{array}$} \\
\hline & & $\begin{array}{l}\text { Per cent } \\
\text { infection }\end{array}$ & ELISA test & $\begin{array}{c}\text { Per cent } \\
\text { infection }\end{array}$ & ELISA test \\
\hline 1. & CS-43 & 15.0 & + & 6.0 & + \\
\hline 2. & CS-45 & 14.0 & + & 6.0 & + \\
\hline 3. & CS-51 & 14.0 & + & 7.0 & + \\
\hline 4. & CS-54 & 18.0 & + & 8.0 & + \\
\hline 5. & CS-55 & 16.0 & + & 9.0 & + \\
\hline 6. & CS-73 & 19.0 & + & 8.0 & + \\
\hline 7. & CS-77 & 16.0 & + & 6.0 & + \\
\hline 8. & CS-82 & 18.0 & + & 7.0 & + \\
\hline 9. & CS-83 & 18.0 & + & 8.0 & + \\
\hline 10. & CS-86 & 22.0 & + & 9.0 & + \\
\hline 11. & CS-92 & 21.0 & + & 9.0 & + \\
\hline 12. & CS-94 & 23.0 & + & 10.0 & + \\
\hline 13. & CS-104 & 17.0 & + & 7.0 & + \\
\hline 14. & CS-120 & 18.0 & + & 8.0 & + \\
\hline 15. & CS-137 & 19.0 & + & 8.0 & + \\
\hline 16. & CS-156 & 20.0 & + & 9.0 & + \\
\hline 17. & CS-202 & 21.0 & + & 8.0 & + \\
\hline 18. & CS-246 & 20.0 & + & 9.0 & + \\
\hline 19. & CS-262 & 22.0 & + & 11.0 & + \\
\hline 20. & CS-268 & 25.0 & + & 13.0 & + \\
\hline 21. & $\mathrm{KRG}-1^{\mathrm{c}}$ & 100.0 & + & 40.0 & + \\
\hline
\end{tabular}

a - Mean per cent of infection from inoculated leaves

$\mathrm{b}$ - Mean per cent of infection from subsequently produced leaves

$\mathrm{C}$ - Susceptible check

+ : Virus present

Field conditions

Host plant resistance is considered to be the most practical and effective method for the management of viral diseases in crops. Among 419 interspecific derivatives screened, nine genotypes recorded as resistant along with promising yield and pod features and 
these genotypes offer promising sources for resistance to use in breeding programmes to develop PBND resistant agronomically high yielding varieties. Complete resistance to PBNV has not been found among cultivated groundnut (Reddy et al., 1991). The results indicated that there was considerable variability in genotypes for resistance to PBNV. In natural condition, field resistant genotypes took a longer time for expression of symptoms and virus multiplication The genotypes CS-21, CS-77, CS-83, CS-85, CS86, CS-124, CS-180 and CS-222 have been registered has potential germplasm under the plant germplasm registration system of Indian Council of Agricultural Research. These genotypes can be exploited in development of PBND resistant varieties.

\section{Glasshouse conditions}

1) Correlation among $t_{50}$, DFSA, DLSA) and PBND (\%) incidence indicated that the earlier the initiation of the symptom early to reach the maximum disease pressure. The cultivar with ability to delay the initiation of symptom will have less final disease pressure (Gopal et al., 2010). So, these epidemiological may very useful in finding out the resistant sources against PBND where, the disease resistance seem to be quantitative nature and there is no complete resistance available against the virus and most of the available sources are of field resistant only.

2) The inoculated and subsequently produced leaves contain PBNV detected by ELISA. So, it appears that resistance mechanism may involve a block in the systemic virus movement or resistance of genotypes to thrips vector. However systemically infected leaves showed less systemic spread than susceptible varieties (Buiel 1995). Many genotypes viz., ICG5044, ICG1656 and ICG799 showed resistance to the vector (Reddy et al., 1983) but they were susceptible to PBNV when tested in glasshouse condition.

\section{References}

Amin, P. W., (1985). Apparent resistance of groundnut cultivar Robut 33-1to bud necrosis disease. Pl. Dis. 69, 718-719.

Basu, M. S., (1995). Peanut bud necrosis: activities in the Indian national programme. In Proc. meeting of recent studies on peanut bud necrosis disease. ICRISAT Asia centre. India, pp. 61-63.

Buiel, A. A. M., (1995). Quantification of disease resistance to peanut bud necrosis tospovirus in groundnut. Wagenengen, Netherlands, Washington Agr. Univ., Doctoral thesis, pp 135.

Buiel, A. A. M., and Parlevliet, J. E., (1995). Epidemiology of peanut bud necrosis disease in groundnut in India. In Proc. meeting of recent studies on peanut bud necrosis disease. ICRISAT Asia centre. India, pp. 41-46.

Dwivedi, S. L., Nigam, S. N., Reddy, D. V. R., Reddy, A. S., Ranga Rao, G.V., (1995). In Proc. workshop on collaborative research for bud necrosis disease. ICRISAT Asia centre. India, pp. 35-40.

Dwivedi, S. L., Reddy, D. V. R., Nigam, S. N., Ranga Rao, G. V., Wightman, J. A., Amin, P. W., Nagabhusham, G. V. S., Reddy, A. S., Scholarberg, F., Ramraj, V. M., (1993). Registration of ICGS 86031 peanut germplasm. Crop Sci. 33, 220.

Ghanekar, A. M., Reddy, D. V. R., Iizuka, N., Amin, P. W., Gibbson, R. W., (1979). Bud necrosis of groundnut (Arachis hypogaea L.) in India caused by tomato spotted wilt virus. Ann. Appl. Biol. 93, 173-179.

Gopal, K., Sreenivasulu, Y., Gopi, V., Subasini, P., Khayum Ahammed, S., Govindaraju, B., Purushotham, K., (2010). Resistant sources in groundnut germplasm lines against peanut bud necrosis tospovirus disease. Arch. 
Phytopathol. Pl. Protect. 43, 501-506. Gururaj Sunkad., Kenchanagoudar, P. V., Naragund, V. B., (2001). Identification of sources for field resistance to peanut bud necrosis disease in groundnut. Karnataka J. Agric. Sci. 15, 646-648.

Lavakumar, P., Jones, A. T., Waliyar, F., Saxena, K. B., (2007b). Screening genotypes for virus resistance. In methods manual on diagnosis and detection of viruses infecting ICRISAT mandate crops. ICRISAT Asia centre, India. 69-71.

Lavakumar, P., Sreenivasulu, P., Waliyar, F., (2007a). Diagnosis of virus diseases, In methods manual on diagnosis and detection of viruses infecting ICRISAT mandate crops. ICRISAT Asia centre, India. 22-25.

Murthy. U. R., Jhanvi, M. R., (1983). Breeding potential of interspecific tetraploids in Arachis L. In: cytogenetics of Arachis, ICRISAT, 125130.

Nagarajan, S., Murlidharan, K., 1995. Dynamics of plant disease. Allied Pub. Ltd. pp. 247

Patil, S.A., 1993. Bud necrosis disease in Karnataka. In Proc. workshop on collaborative research in India in breeding groundnuts for resistance to bud necrosis disease. ICRISAT Asia centre. India, pp. 28-31.

Ramamurthi Jambunathan., Madhusudana
Raju, S., Shubhada, P. B., (1985). Analysis of oil content of groundnuts by nuclear magnetic resonance spectrometry. J. Sci. Food and Agri. 36, 162-166.

Reddy, A. S., Reddy, L. J., Nalini Mallikarjuna, Abdurahman, M. D., Reddy, Y. V., Bramel, P. J., Reddy, D. V. R., (2000). Identification of resistance to peanut bud necrosis virus (PBNV) in wild Arachis germplasm. Ann. Appl. Biol. 137, 135-139.

Reddy, D. V. R., Amin, P. W., McDonald, D., Ghanekhar, A. M., (1983). Epidemiology and control of groundnut bud necrosis and other diseases of legume crops in India caused by tomato spotted wilt virus. Plant Virus Epidemiology. 93-102.

Reddy, D. V. R., Wightman, J. A., Beshear, R. J., Higland, B., Black, M., Srinivasulu, P., Dwivedi, S. L., Demski, J. W., McDonald, D., Smith, J. W., Smith, D. H., (1991). Bud necrosis: A disease of groundnut caused by tomato spotted wilt virus. Information bulletin No.13.

Vijaya Lakshmi, K., (1994). Transmission and ecology of Thrips palmi Karny, the vector of peanut bud necrosis virus. Andhra Pradesh Agri. Univ., Doctoral thesis.

\section{How to cite this article:}

Muttanna Revadi, Gururaj Sunkad, A. Srinivasaraghavan and Bera, S.K. 2018. Search for Potential Sources of Resistance among Interspecific Derivatives of Peanut against Peanut Bud Necrosis Disease. Int.J.Curr.Microbiol.App.Sci. 7(01): 2731-2739.

doi: https://doi.org/10.20546/ijcmas.2018.701.327 